\title{
Effect of Small Content of Chromium on Wet-Dry Acid Corrosion Behavior of Low Alloy Steel
}

\author{
Qing-He Zhao ${ }^{1} \cdot$ Wei Liu ${ }^{1} \cdot$ Yi-Chun Zhu ${ }^{1} \cdot$ Bin-Li Zhang ${ }^{1} \cdot$ Shuan-Zhu Li $^{1} \cdot$ Min-Xu Lu ${ }^{1}$
}

Received: 8 July 2016/Revised: 3 September 2016/Published online: 4 November 2016

(C) The Chinese Society for Metals and Springer-Verlag Berlin Heidelberg 2016

\begin{abstract}
Effect of small content of chromium (Cr) on wet-dry acid corrosion behavior of low alloy steels has been investigated. The results show that the corrosion resistance of the steels increased with increasing $\mathrm{Cr}$ content from 0.10 to $0.50 \mathrm{wt} \%$. Higher content of $\mathrm{Cr}$ promotes initial corrosion and accelerates the formation of dense and protective rust in long-term corrosion. The enhanced protectiveness of the rust is closely related to its composition. High content of $\mathrm{Cr}$ increases the content of amorphous phases and decreases the content of $\gamma-\mathrm{FeOOH}$ in the rust, resulting in the high compactness of the rust and low electrochemical activity in acid condition. $\mathrm{Cr}$ dopes in rust and depresses the transformation from amorphous phases to $\alpha-\mathrm{FeOOH}$, as well as the growth process of $\mathrm{FeOOH}$ particles, which is responsible for the enhanced compactness of rust in long-term corrosion.
\end{abstract}

KEY WORDS: Low alloy steel; Chromium; Corrosion; EIS; TEM

\section{Introduction}

Alloying chromium $(\mathrm{Cr})$ has been proved to be effective in increasing the corrosion resistance of low alloy steel under various corrosion environments, such as atmospheric corrosion and oil and gas industrial $\mathrm{CO}_{2}$ corrosion [1-5]. In atmospheric corrosion, $\mathrm{Cr}$ is enriched in the inner rust of the steel after long-term corrosion [6-9]. Cr-rich dense and protective inner rust mainly consists of nano-sized goethite $[10,11]$, which is electrochemically stable, and depresses both metal dissolution and oxygen reduction process of the rusted steel due to the strongly aggregated structure $[12,13]$.

Available online at http://link.springer.com/journal/40195

Wei Liu

weiliu@ustb.edu.cn

1 Institute for Advanced Materials and Technology, University of Science and Technology Beijing, Beijing 100083, China
Ion selectivity of rust changes from anion selectivity to cation selectivity with certain amount of $\mathrm{Cr}^{3+}$ ions (about 5-10 wt\%) substituting $\mathrm{Fe}^{3+}$ ions in goethite, and the penetration of corrosive anions such as $\mathrm{Cl}^{-}$and $\mathrm{SO}_{4}{ }^{2-}$ can be hindered [14, 15]. Cr can also inhibit cathodic corrosion process during drying-out stage of atmospheric corrosion $[16,17]$. In $\mathrm{CO}_{2}$ corrosion conditions, $\mathrm{Cr}(\geq 2 \mathrm{wt} \%)$ promotes its enrichment in corrosion scale, preventing both anodic dissolution and cathodic reduction process of steel $[5,18]$.

The enhancing effect of $\mathrm{Cr}$ on corrosion resistance of the steel in atmospheric corrosion and $\mathrm{CO}_{2}$ corrosion conditions has been widely reported, but the effect of $\mathrm{Cr}$ on wetdry acid corrosion behavior of the steels in vapor space of crude oil tanker was rarely investigated, where the steel is exposed to the acid corrosive atmosphere containing certain amount of $\mathrm{O}_{2}, \mathrm{H}_{2} \mathrm{~S}, \mathrm{CO}_{2}$ and $\mathrm{SO}_{2}$ with cyclic wet-dry process [19-21]. The corrosion of the steel in such a wetdry acid corrosion condition was severe, and corrosion resistant low alloy steel can be an effective way to prolong the service life of crude oil tanker [22, 23]. Besides, $\mathrm{Cr}$ content of steel in above investigations was all higher than 
$1 \mathrm{wt} \%$, and rare investigations focused on corrosion behavior of steel with $\mathrm{Cr}$ content smaller than $0.5 \mathrm{wt} \%$, which was vital for developing economic corrosion resistant steel [24]. Thus, it is of great importance to illustrate the effect of small content of $\mathrm{Cr}$ on wet-dry acid corrosion behavior of low alloy steel.

The effect of small content of $\mathrm{Cr}$ on wet-dry acid corrosion behavior of steels was investigated in this paper. The potentiodynamic polarization and electrochemical impedance spectroscopy (EIS) are used to analyze the electrochemical corrosion behavior of the steels. Other analytical methods such as XRD, SEM, TEM and $\mathrm{N}_{2}$ adsorption are used to analyze the phase composition, morphologies and compactness of the rust.

\section{Experimental}

\subsection{Tested Steels and Corrosion Test}

Table 1 shows the chemical composition of the tested steels with increasing $\mathrm{Cr}$ content from 0.10 to $0.50 \mathrm{wt} \%$. The steels were obtained by melting the constituent elements in a vacuum induction furnace and then followed by casting the melt into slabs. The cast slabs were reheated at $1200{ }^{\circ} \mathrm{C}$ for $2 \mathrm{~h}$ and then hot rolled into the plates with thickness of $18 \mathrm{~mm}$. The microstructures of three steels consist of fine acicular ferrite as dominant phases with small amount of carbon-rich phases (Fig. 1). The microstructures of $0.50 \mathrm{Cr}$ and $0.20 \mathrm{Cr}$ steels are finer than that of $0.10 \mathrm{Cr}$ steel. $\mathrm{Cr}$ exists mainly in ferrite of the steels as solid solution state.

The specimens were machined into the size of $60 \mathrm{~mm} \times 25 \mathrm{~mm} \times 5 \mathrm{~mm}$ and then abraded gradually to 600 grade with silicon carbide emery paper. Then the specimens were cleaned in acetone and alcohol, weighted by an electronic analytical balance with an accuracy of $0.1 \mathrm{mg}$. The width and length of the specimens were measured by a vernier caliper with an accuracy of $0.02 \mathrm{~mm}$ and then stored in a moisture-free desiccator. Before corrosion test, the specimens were enclosed with silica gel with an exposure area of $60 \mathrm{~mm} \times 25 \mathrm{~mm}\left(1500 \mathrm{~mm}^{2}\right)$.

Figure 2 shows the schematic of test device for simulating the wet-dry acid corrosion environment. The test device is composed of temperature control and record system, acid gas

Table 1 Chemical compositions of tested steels (wt \%)

\begin{tabular}{llllllllll}
\hline Steel & $\mathrm{C}$ & $\mathrm{Si}$ & $\mathrm{Mn}$ & $\mathrm{S}$ & $\mathrm{P}$ & $\mathrm{Cu}$ & $\mathrm{Ni}$ & $\mathrm{Cr}$ & $\mathrm{Fe}$ \\
\hline $0.10 \mathrm{Cr}$ & 0.08 & 0.24 & 1.05 & 0.002 & 0.007 & 0.30 & 0.20 & 0.10 & Bal. \\
$0.20 \mathrm{Cr}$ & 0.08 & 0.24 & 1.06 & 0.002 & 0.006 & 0.30 & 0.20 & 0.20 & Bal. \\
$0.50 \mathrm{Cr}$ & 0.08 & 0.24 & 1.04 & 0.002 & 0.006 & 0.30 & 0.20 & 0.50 & Bal. \\
\hline
\end{tabular}

atmosphere control system, and a closed container. The acid gas inside the test device consists of 4 vol. $\% \mathrm{O}_{2}, 13$ vol.\% $\mathrm{CO}_{2}, 500 \mathrm{ppm} \mathrm{H}_{2} \mathrm{~S}, 100$ ppm $\mathrm{SO}_{2}$ and $\mathrm{N}_{2}$ balance, and is continuously put into and flew out of the container. The gas flow rate is $100 \mathrm{~mL} / \mathrm{min}$ in first $24 \mathrm{~h}$, then $10 \mathrm{~mL} / \mathrm{min}$ after $24 \mathrm{~h}$. Specimens are fixed on the top of the container, and the temperature of the specimens is controlled by controlling the temperature on top cover of the container. Specimens are kept at $50{ }^{\circ} \mathrm{C}$ for $19 \mathrm{~h}, 25{ }^{\circ} \mathrm{C}$ for $3 \mathrm{~h}$, and the transition time between 50 and $25^{\circ} \mathrm{C}$ is $2 \mathrm{~h}$. Each cycle equals to $24 \mathrm{~h}$. The distilled water is beneath the specimens, and the temperature of distilled water is kept between 30 and $32{ }^{\circ} \mathrm{C}$. The distance between the specimens and distilled water is $180 \mathrm{~mm}$ to avoid the splash of water [23, 24]. Thus, the acid electrolyte film forms and disappears cyclically on the specimen surface, and electrochemical corrosion occurs. The total corrosion time is 98 days, and the specimens are corroded with 7, 21, 35, 49 and 98 days, respectively.

\subsection{Rust Analysis}

The surface and cross-sectional morphologies of the rust are characterized by SEM. Quantitative analysis of phase composition of the rusts is analyzed using XRD with a $\mathrm{Cu}$ target. Rust powders are prepared for quantitative phase analysis, and $\mathrm{ZnO}$ is the internal standard [25]. The scan speed of XRD is $2.0^{\circ} / \mathrm{min}$, and the range of $2 \theta$ is from $10^{\circ}$ to $60^{\circ}$. Rust in wet-dry acid corrosion condition mainly contains amorphous phases, goethite $(\alpha-\mathrm{FeOOH})$, lepidocrocite $(\gamma-\mathrm{FeOOH})$, magnetite $\left(\mathrm{Fe}_{3} \mathrm{O}_{4}\right)$ and elemental $\mathrm{S}$. The diffraction intensities of (011) reflection of $\alpha-\mathrm{FeOOH},(020)$ reflection of $\gamma$ $\mathrm{FeOOH}$, (220) reflection of $\mathrm{Fe}_{3} \mathrm{O}_{4}$ and (222) reflection of elemental $\mathrm{S}$ are measured and compared with (100) reflection of $\mathrm{ZnO}$ powder. The $\mathrm{ZnO} /$ rust ratio is 1:9. Thus, the content of $\alpha$-FeOOH, $\gamma$-FeOOH, $\mathrm{Fe}_{3} \mathrm{O}_{4}$ and elemental $\mathrm{S}$ can be obtained, and amorphous phases are the balance.

The adsorption isotherm of $\mathrm{N}_{2}$ on the rust is measured using a surface area and pore size analyzer, and the specific surface area (SSA) of the rust is determined by fitting the BET equation to the adsorption isotherms using crosssectional area $\left(0.162 \mathrm{~nm}^{2}\right)$ of $\mathrm{N}_{2}$ molecule [3, 16]. The morphology and electronic diffraction patterns of the rust are characterized using TEM (FEI Tecnai F20).

\subsection{Electrochemical Tests}

The electrochemical tests are conducted by an electrochemical workstation with a three-electrode system. The working electrode is corroded steels, the auxiliary electrode is the platinum plate with size of $15 \mathrm{~mm} \times 15 \mathrm{~mm} \times 0.5 \mathrm{~mm}$, and the reference electrode is saturated calomel electrode. The condensate water in the wet-dry acid environments contains certain amount of $\mathrm{SO}_{4}{ }^{2-}$ due to the existence of $\mathrm{SO}_{2}$ 

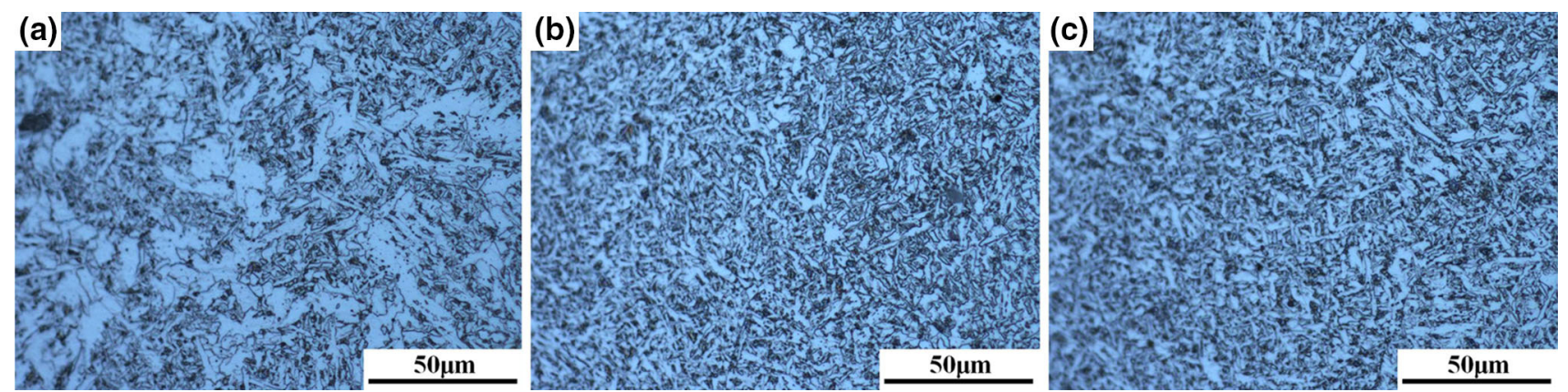

Fig. 1 Microstructures of the tested steels with different $\mathrm{Cr}$ contents: a $0.10 \mathrm{Cr}$; b $0.20 \mathrm{Cr}$; $\mathbf{c} 0.50 \mathrm{Cr}$

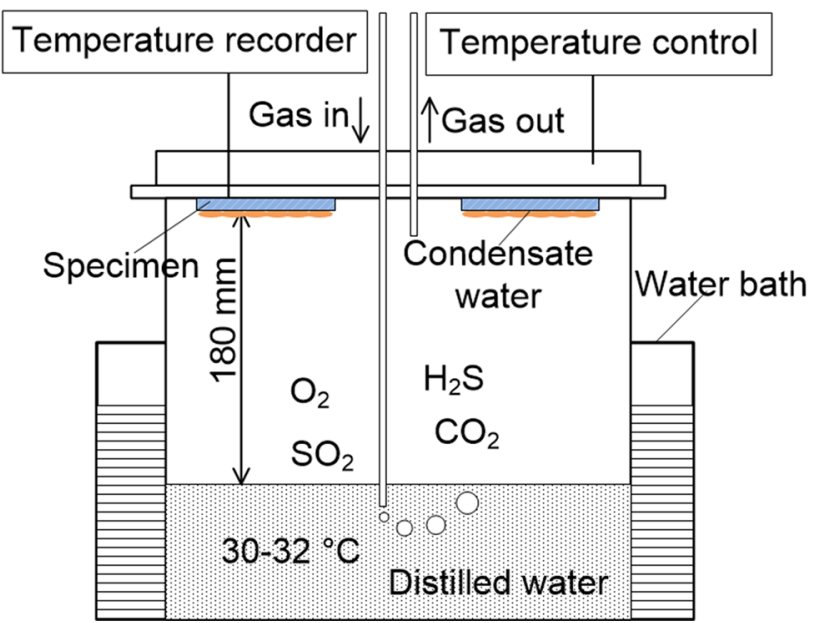

Fig. 2 Schematic diagram of the wet-dry acid corrosion test device

and $\mathrm{O}_{2}, \mathrm{pH}$ value of which is about $2-4$ [20]. $0.1 \mathrm{~mol} / \mathrm{L}$ $\mathrm{Na}_{2} \mathrm{SO}_{4}$ solution with $\mathrm{pH}$ value of 3.0 and temperature of $25{ }^{\circ} \mathrm{C}$ is used for the electrochemical tests. Electrochemical tests are conducted in acid electrolyte after the immersion of 30 min when open-circuit potential (OCP) of corroded steels is stabilized. Linear polarization test is conducted at a sweep rate of $0.167 \mathrm{mV} / \mathrm{s}$ in the range of $\pm 10 \mathrm{mV}$ versus OCP for obtaining linear polarization resistance $R_{\mathrm{p}}$. Potentiodynamic polarization curves of the steels are conducted at a sweep rate of $0.5 \mathrm{mV} / \mathrm{s}$ in the range of $\pm 250 \mathrm{mV}$ versus OCP. EIS is measured at the frequency range from $100 \mathrm{kHz}$ to $10 \mathrm{mHz}$ at OCP with perturbing sinusoidal excitation signal of $5 \mathrm{mV}$, and there are twelve points per frequency decade. The measured EIS plots are fitted and calculated by ZSimpWin software, and the relative error is lesser than 5\%.

\section{Results}

\subsection{Corrosion Kinetics}

Figure 3 shows the corrosion loss and corrosion rate of the tested steels in wet-dry acid corrosion environment. The corrosion loss increases gradually with increasing corrosion time. The corrosion rate of the steels firstly increased from 7 to 21 days and then decreased from 21 to 98 days. Corrosion rate of the steels at corrosion time of 21 days is in the following order: $0.50 \mathrm{Cr}>0.20 \mathrm{Cr}>0.10 \mathrm{Cr}$, which indicates that increasing content of $\mathrm{Cr}$ accelerates the initial wet-dry acid corrosion rate of steel. Meanwhile, corrosion rate at corrosion time of 98 days from high to low is as follows: $0.10 \mathrm{Cr}>0.20 \mathrm{Cr}>0.50 \mathrm{Cr}$, which indicates that high content of $\mathrm{Cr}$ decreases the long-term corrosion rate of the steels.

Table 2 gives the fitted corrosion kinetics of tested steels in wet-dry acid corrosion. The corrosion kinetics of the steels can be fitted by the formula of $C_{\mathrm{L}}=A \times C_{\mathrm{T}}^{\mathrm{b}}$ [26], where $C_{\mathrm{L}}$ is the corrosion loss $(\mathrm{mm}), C_{\mathrm{T}}$ is the corrosion time (day), $A$ and $b$ are the constants relating to the corrosion kinetics. $b$ value in the formula reflects the characteristics of corrosion kinetics of steels. $b<1$ means a corrosion deceleration process, $b=1$ means a constant corrosion process, and $b>1$ means a corrosion acceleration process [26]. $b$ value is $0.859,0.827$ and 0.877 for $0.10 \mathrm{Cr}, 0.20 \mathrm{Cr}$ and $0.50 \mathrm{Cr}$ steel, respectively, indicating that high $\mathrm{Cr}$ steel presents enhanced corrosion resistance in wet-dry acid corrosion.

\subsection{Potentiodynamic Polarization Curves}

Figure 4 shows the potentiodynamic polarization curves of the tested steels. Figure $4 \mathrm{a}$ shows that the cathodic polarization reaction of bare steels is mainly controlled by the reduction of dissolved oxygen, while the anodic polarization reaction of bare steels is dominated by the steel dissolution process [27]. Meanwhile, the self-corrosion potential of $0.50 \mathrm{Cr}$ steel is more negative than that of $0.10 \mathrm{Cr}$ and $0.20 \mathrm{Cr}$ steel.

Figure $4 \mathrm{~b}-\mathrm{f}$ indicates that the cathodic polarization reaction of the rusted steel is different from that of bare steel, and is mainly dominated by the reduction of electrochemical active rust, and the anodic polarization reaction is depressed by the coverage of the rust [28]. The 

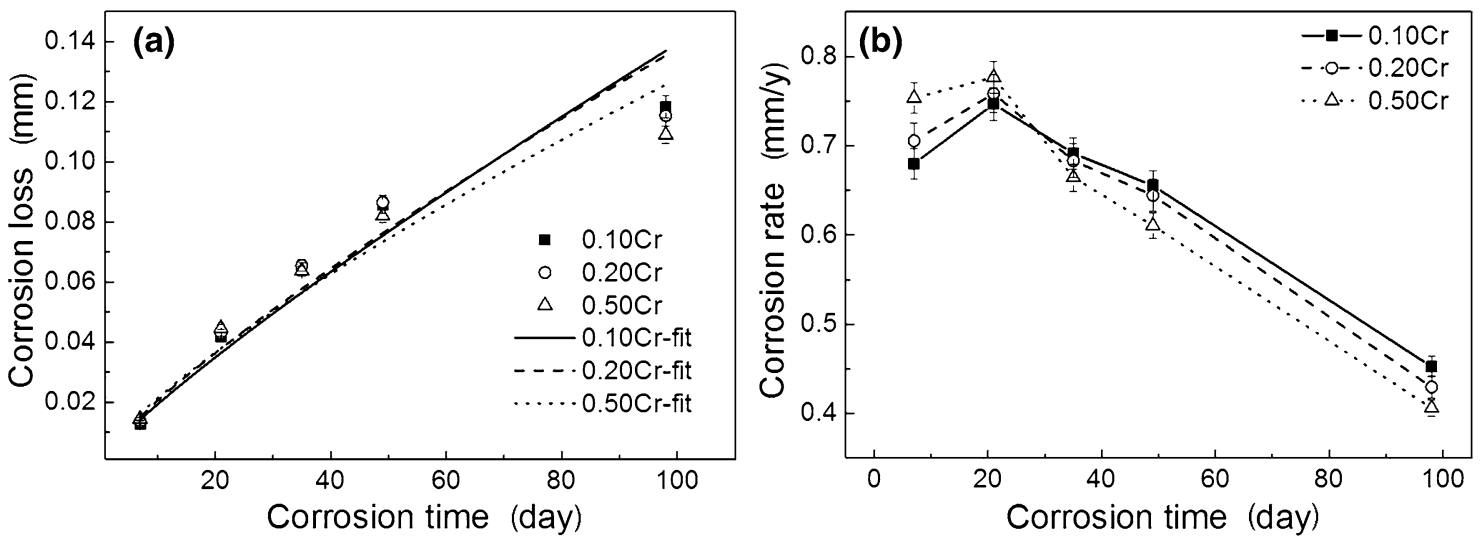

Fig. 3 Corrosion kinetics of the tested steels under wet-dry acid corrosion environment: a corrosion loss-corrosion time; b corrosion ratecorrosion time

Table 2 Fitted corrosion kinetics of tested steels in wet-dry acid corrosion environment

\begin{tabular}{lll}
\hline Steel & Fitted kinetics & $R^{2}$ \\
\hline $0.10 \mathrm{Cr}$ & $C_{\mathrm{L}}=0.0026 \times C_{\mathrm{T}}^{0.859}$ & 0.964 \\
$0.20 \mathrm{Cr}$ & $C_{\mathrm{L}}=0.0030 \times C_{\mathrm{T}}^{0.827}$ & 0.956 \\
$0.50 \mathrm{Cr}$ & $C_{\mathrm{L}}=0.0035 \times C_{\mathrm{T}}^{0.777}$ & 0.960 \\
\hline
\end{tabular}

cathodic and anodic currents of the rusted steels increased with increasing content of $\mathrm{Cr}$ at corrosion time of 7 and 21 days, while it shows the opposite results at corrosion time from 35 to 98 days, indicating that high content of $\mathrm{Cr}$ promotes the initial corrosion, and depresses the long-term corrosion of rusted steels. Particularly, at corrosion time of 98 days, high $\mathrm{Cr}$ steel $(0.50 \mathrm{Cr})$ presents more positive corrosion potential, and lower corrosion current in acid corrosion condition.

Table 3 gives the fitted parameters of linear polarization and potentiodynamic polarization curves. Linear polarization resistance $R_{\mathrm{p}}$ of the steels is calculated from the linear polarization plots using equation of $R_{\mathrm{p}}=\mathrm{d} E / \mathrm{d} i$, where $E$ is polarization potential of the steels versus SCE, and $i$ is polarization current density of the steels corresponding potential [29]. Self-corrosion current densities $\left(i_{\text {corr }}\right)$ of bare and rusted steels are calculated with equations of $i_{\text {corr }}=B / R_{\mathrm{p}}$, and $B=\beta_{\mathrm{a}} \beta_{\mathrm{c}} /\left(\beta_{\mathrm{a}}+\beta_{\mathrm{c}}\right)$ [30], where $i_{\text {corr }}$ is self-corrosion current density of the steels, $R_{\mathrm{p}}$ is linear
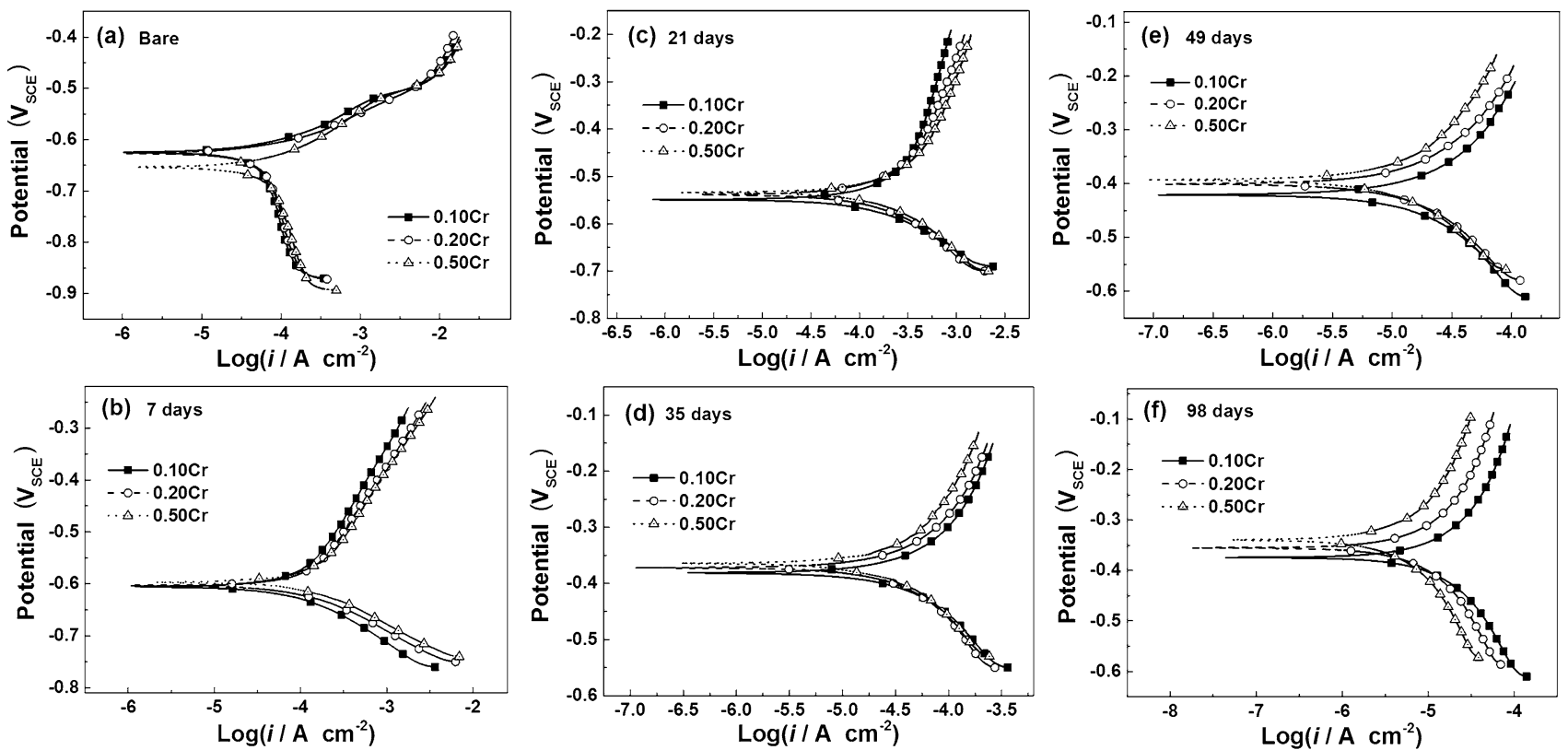

Fig. 4 Potentiodynamic polarization curves of the tested steels with increasing corrosion time: a bare steels; b 7 days; c 21 days; d 35 days; e 49 days; $\mathbf{f} 98$ days 
Table 3 Fitted parameters of the linear polarization and potentiodynamic polarization curves of bare and rusted steels

\begin{tabular}{|c|c|c|c|c|c|}
\hline Steel & $\beta_{\mathrm{a}}(\mathrm{mV} / \mathrm{dec})$ & $\beta_{\mathrm{c}}(\mathrm{mV} / \mathrm{dec})$ & $R_{\mathrm{p}}\left(\Omega \mathrm{cm}^{2}\right)$ & $E_{\text {corr }}\left(\mathrm{V}_{\mathrm{SCE}}\right)$ & $i_{\text {corr }}\left(\mu \mathrm{A} / \mathrm{cm}^{2}\right)$ \\
\hline \multicolumn{6}{|l|}{ Bare } \\
\hline $0.10 \mathrm{Cr}$ & 29.2 & 221.3 & 400.2 & -0.625 & 64.4 \\
\hline $0.20 \mathrm{Cr}$ & 29.9 & 224.6 & 371.5 & -0.628 & 71.0 \\
\hline $0.50 \mathrm{Cr}$ & 31.0 & 205.7 & 338.4 & -0.654 & 79.6 \\
\hline \multicolumn{6}{|l|}{7 days } \\
\hline $0.10 \mathrm{Cr}$ & 121.0 & 48.0 & 276.0 & -0.605 & 124.6 \\
\hline $0.20 \mathrm{Cr}$ & 107.4 & 39.9 & 194.3 & -0.604 & 149.6 \\
\hline $0.50 \mathrm{Cr}$ & 108.7 & 39.1 & 162.3 & -0.599 & 177.3 \\
\hline \multicolumn{6}{|l|}{21 days } \\
\hline $0.10 \mathrm{Cr}$ & 122.7 & 57.4 & 191.8 & -0.550 & 203.9 \\
\hline $0.20 \mathrm{Cr}$ & 129.1 & 74.2 & 197.6 & -0.540 & 238.4 \\
\hline $0.50 \mathrm{Cr}$ & 119.7 & 78.9 & 169.3 & -0.535 & 281.0 \\
\hline \multicolumn{6}{|l|}{35 days } \\
\hline $0.10 \mathrm{Cr}$ & 117.9 & 100.3 & 784.7 & -0.381 & 69.1 \\
\hline $0.20 \mathrm{Cr}$ & 119.8 & 96.6 & 925.0 & -0.371 & 57.8 \\
\hline $0.50 \mathrm{Cr}$ & 117.1 & 91.5 & 1057.3 & -0.365 & 48.6 \\
\hline \multicolumn{6}{|l|}{49 days } \\
\hline $0.10 \mathrm{Cr}$ & 103.2 & 103.2 & 2069.0 & -0.421 & 25.5 \\
\hline $0.20 \mathrm{Cr}$ & 102.2 & 89.3 & 2330.5 & -0.401 & 20.3 \\
\hline $0.50 \mathrm{Cr}$ & 104.6 & 90.0 & 2929.1 & -0.395 & 16.5 \\
\hline \multicolumn{6}{|l|}{98 days } \\
\hline $0.10 \mathrm{Cr}$ & 115.1 & 126.6 & 3293.2 & -0.374 & 18.3 \\
\hline $0.20 \mathrm{Cr}$ & 116.0 & 129.4 & 4649.6 & -0.354 & 13.2 \\
\hline $0.50 \mathrm{Cr}$ & 118.8 & 126.7 & 7086.5 & -0.340 & 8.7 \\
\hline
\end{tabular}

polarization resistance, $B$ is a constant relating to cathodic and anodic polarization behavior of the steels, and $\beta_{\mathrm{a}}$ and $\beta_{\mathrm{c}}$ are anodic and cathodic polarization rates.

With increasing $\mathrm{Cr}$ content from 0.10 to $0.50 \mathrm{wt} \%, i_{\text {corr }}$ increases for bare steel and at corrosion time of 7 and 21 days, respectively, indicating that high content of $\mathrm{Cr}$ can promote the initial corrosion of the steel, which is consistent with corrosion rate results in Fig. 3. $i_{\text {corr }}$ of the steels decreases rapidly from corrosion time of 21-35 days, which may be related to dense protective rust forming on steel surface. $i_{\text {corr }}$ of the steels continues to decrease from corrosion time of 35-98 days, indicating that the protectiveness of rust increases as corrosion proceed. $i_{\text {corr }}$ of the rusted steels decreases with increasing $\mathrm{Cr}$ content from corrosion time of 35-98 days, which indicates that high content of $\mathrm{Cr}$ can depress the long-term corrosion of rusted steels.

\subsection{EIS Plots}

Figure 5 shows the EIS plots of bare steels in acid electrolyte. Figure 5a shows that the Nyquist plots of bare steels consist of one semicircle representing the charge transfer process, and one inductance impedance [21, 31]. Figure $5 \mathrm{~b}$ indicates that the time constant relating to the charge transfer process is located in the middle-frequency region, and the inductance impedance is observed in the low-frequency region.

A proposed general equivalent electrical circuit is depicted in Fig. 6. Elements are as follows: $R_{\mathrm{s}}$ is electrolyte resistance, $R_{\text {ct }}$ is charge transfer resistance in steel/rust interface, $Q_{\mathrm{dl}}$ is double-layer capacitance as a constant phase-angle element (CPE), $R_{\mathrm{L}}$ is electrical inductance, and $L$ is inductance element [21]. Table 4 shows the fitted parameters for bare steels. The results shows that $R_{\mathrm{ct}}$ of bare steels decreased with increasing $\mathrm{Cr}$ content, indicating that high content of $\mathrm{Cr}$ promotes the dissolution of bare steel in acid electrolyte.

Figure 7 shows the EIS plots of rusted steels. Figure 7a, c, $\mathrm{e}, \mathrm{g}, \mathrm{i}$ shows that the Nyquist plots of the rusted steel consist of one incomplete impedance semicircle in the high-frequency region, and another incomplete impedance semicircle with a diffusion tail in middle- and low-frequency region [21, 32]. Figure 7b shows two time constants at high- and 

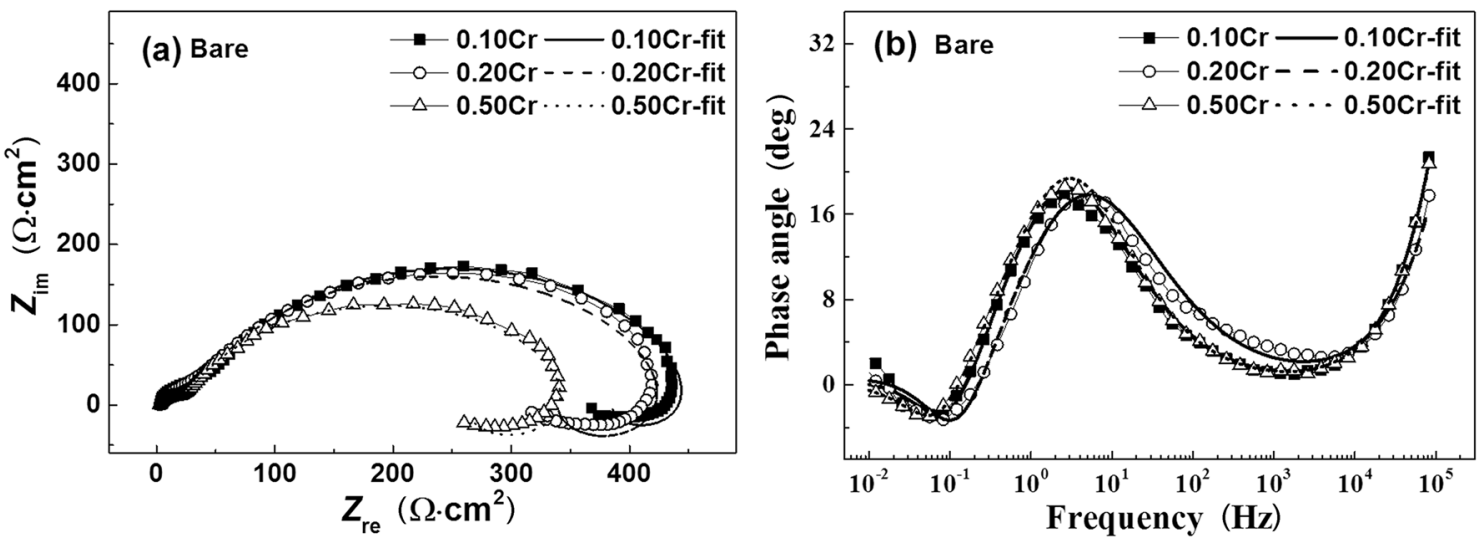

Fig. 5 EIS plots of bare steels in $0.1 \mathrm{~mol} / \mathrm{L} \mathrm{Na}_{2} \mathrm{SO}_{4}$ solution with $\mathrm{pH} 3.0$ and at the temperature of $25{ }^{\circ} \mathrm{C}$ : a Nyquist plots; $\mathbf{b}$ Bode plots

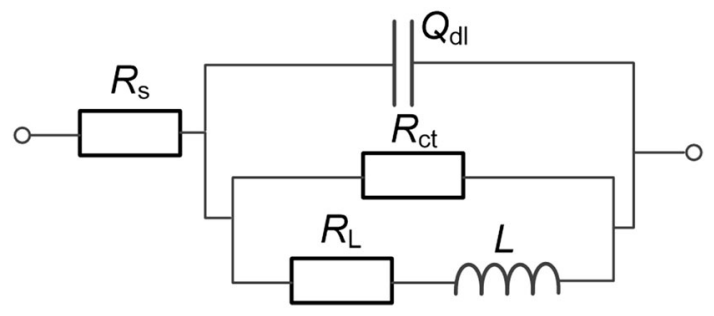

Fig. 6 Equivalent circuit for simulating the EIS plots of bare steels

low-frequency regions, relating to the rust resistance $R_{\text {rust }}$ and charge transfer resistance $R_{\mathrm{ct}}$ in steel/rust interface, respectively [33]. As corrosion proceeds, the phase angle of the rusted steels decreases in low-frequency region, and increases in the high-frequency region.

A proposed general equivalent electrical circuit is depicted in Fig. 8. Elements are as follows: $R_{\mathrm{S}}$ is electrolyte resistance, $Q_{\text {rust }}$ is capacitance resistance, and $R_{\text {rust }}$ is rust resistance, $R_{\mathrm{ct}}$ is charge transfer resistance, and $Q_{\mathrm{dl}}$ is double-layer capacitance in steel/rust interface, $W$ is Warburg resistance relating to diffusion of corrosive species $[21,32]$.

Table 5 gives the fitted parameters of EIS plots for the rusted steels. For the rusted steels at corrosion time of 7 days, $R_{\text {rust }}$ shows little difference, while $R_{\mathrm{ct}}$ decreases obviously with increasing $\mathrm{Cr}$ content. And for the rusted steels at corrosion time of 21 days, $R_{\text {rust }}$ increases slightly, while $R_{\mathrm{ct}}$ decreases obviously with increasing $\mathrm{Cr}$ content. The above results indicate that high $\mathrm{Cr}$ content increases
$R_{\text {rust }}$ slightly, and decreases $R_{\mathrm{ct}}$ of the rusted steels obviously in initial corrosion stage.

At corrosion time of 35 days, both $R_{\text {rust }}$ and $R_{\mathrm{ct}}$ increase rapidly comparing with that at 21 days, indicating the formation of protective rust. Meanwhile, $R_{\text {rust }}$ and $R_{\mathrm{ct}}$ increase with increasing $\mathrm{Cr}$ content, indicating that high $\mathrm{Cr}$ content increases both $R_{\text {rust }}$ and $R_{\mathrm{ct}}$ of the rusted steels at the corrosion time of 35 days. As corrosion proceeds, both $R_{\text {rust }}$ and $R_{\text {ct }}$ increase rapidly from corrosion time of 35-98 days. The above results indicate that high $\mathrm{Cr}$ content can effectively increase $R_{\text {rust }}$ of the rusted steels in longterm corrosion, and then $R_{\mathrm{ct}}$ in steel/rust interface increases with the coverage of dense protective rust.

\subsection{Rust Characteristics}

Figure 9 shows the quantitative rust analysis of the steels at the corrosion time of 21 and 98 days, respectively. The rusts are mainly composed of amorphous phases, $\alpha$ $\mathrm{FeOOH}, \gamma-\mathrm{FeOOH}, \mathrm{Fe}_{3} \mathrm{O}_{4}$ and element $\mathrm{S}$. The content of amorphous phases in the rust increases, while the contents of $\gamma-\mathrm{FeOOH}, \mathrm{Fe}_{3} \mathrm{O}_{4}$ and element $\mathrm{S}$ decrease from corrosion time of 21-98 days. The rust composition of the tested steels presents little difference at corrosion time of 21 days, whereas, for the rusts at corrosion time of 98 days, the content of amorphous phases increases obviously, and the contents of $\alpha-\mathrm{FeOOH}$ and $\gamma$-FeOOH decrease slightly with increasing $\mathrm{Cr}$ content. The results indicate that high content of $\mathrm{Cr}$ promotes the formation of amorphous phase, and

Table 4 Fitted parameters of EIS plot for bare steels in acid electrolyte

\begin{tabular}{lllllll}
\hline Steel & $R_{\mathrm{s}}\left(\Omega \mathrm{cm}^{2}\right)$ & $Q_{\mathrm{dl}}\left(\mathrm{F} \mathrm{cm}^{-2}\right)$ & $n_{\mathrm{dl}}$ & $R_{\mathrm{ct}}\left(\Omega \mathrm{cm}^{2}\right)$ & $R_{\mathrm{L}}\left(\Omega \mathrm{cm}^{2}\right)$ & 130.4 \\
\hline $0.10 \mathrm{Cr}$ & 1.2 & $2.88 \mathrm{E}-04$ & 0.851 & 397.3 & $\mathrm{H} \mathrm{cm}$ & \\
$0.20 \mathrm{Cr}$ & 1.4 & $2.21 \mathrm{E}-04$ & 0.869 & 369.1 & 83.7 & 51.7 \\
$0.50 \mathrm{Cr}$ & 1.3 & $3.29 \mathrm{E}-08$ & 0.796 & 336.6 & 93.2 & 43.5 \\
\hline
\end{tabular}



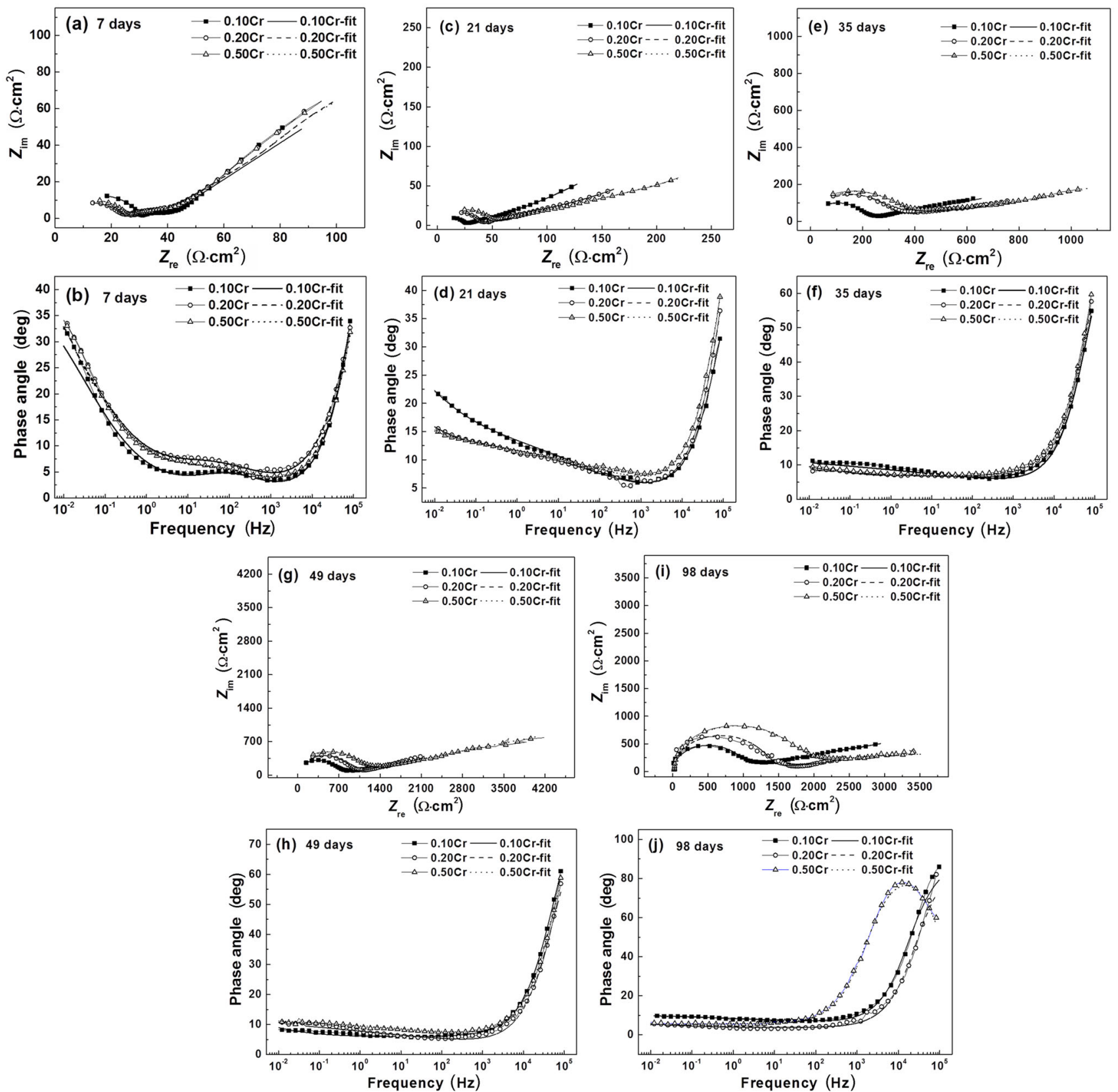

Fig. 7 EIS plots of the rusted steels in $0.1 \mathrm{~mol} / \mathrm{L} \mathrm{Na} \mathrm{SO}_{4}$ solution with $\mathrm{pH} 3.0$ and at temperature of $25^{\circ} \mathrm{C}$ : a, b 7 days; c, d 21 days; e, f 35 days; $\mathbf{g}, \mathbf{h} 49$ days; $\mathbf{i}, \mathbf{j} 98$ days

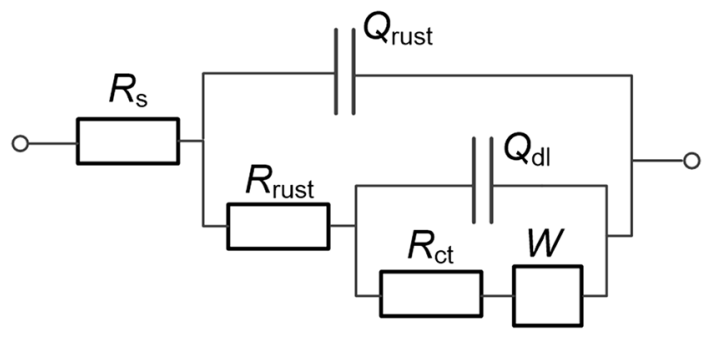

Fig. 8 Equivalent circuit of EIS plots for the rusted steels depresses the formation of $\alpha-\mathrm{FeOOH}$ and $\gamma-\mathrm{FeOOH}$ in the rust in the long-term corrosion.

Figure 10 gives the specific surface areas (SSAs) of the rust obtained from $\mathrm{N}_{2}$ adsorption method at the corrosion time of 21 and 98 days, respectively. SSA is an important index to evaluate the protectiveness of the rust during corrosion [33]. Higher SSA indicates higher compactness and barrier effect of the rust [34]. With increasing $\mathrm{Cr}$ content, SSA of the rust increases slightly at corrosion time 
Table 5 Fitted parameters of EIS plots for rusted specimens at different corrosion time

\begin{tabular}{llllllllll}
\hline Corrosion time & Steel & $R_{\mathrm{s}}\left(\Omega \mathrm{cm}^{2}\right)$ & $Q_{\text {rust }}\left(\mathrm{F} / \mathrm{cm}^{2}\right)$ & $n_{\text {rust }}$ & $R_{\text {rust }}\left(\Omega \mathrm{cm}^{2}\right)$ & $Q_{\mathrm{dl}}\left(\mathrm{F} / \mathrm{cm}^{2}\right)$ & $n_{\mathrm{dl}}$ & $R_{\mathrm{ct}}\left(\Omega \mathrm{cm}^{2}\right)$ & $W\left(\Omega \mathrm{cm}^{2}\right)$ \\
\hline 7 days & $0.10 \mathrm{Cr}$ & 1.2 & $2.91 \mathrm{E}-7$ & 0.897 & 30.8 & $2.45 \mathrm{E}-3$ & 0.617 & 245.2 \\
& $0.20 \mathrm{Cr}$ & 1.4 & $9.72 \mathrm{E}-7$ & 0.797 & 24.8 & $5.78 \mathrm{E}-3$ & 0.479 & 169.5 & 0.0059 \\
& $0.50 \mathrm{Cr}$ & 1.3 & $4.11 \mathrm{E}-7$ & 0.846 & 26.8 & $6.28 \mathrm{E}-3$ & 0.474 & 135.5 & 0.0048 \\
21 days & $0.10 \mathrm{Cr}$ & 1.3 & $2.13 \mathrm{E}-7$ & 0.890 & 27.5 & $1.35 \mathrm{E}-2$ & 0.284 & 164.3 & 0.0015 \\
& $0.20 \mathrm{Cr}$ & 1.1 & $1.23 \mathrm{E}-7$ & 0.920 & 42.7 & $9.62 \mathrm{E}-3$ & 0.261 & 154.9 & 0.0023 \\
& $0.50 \mathrm{Cr}$ & 1.3 & $7.88 \mathrm{E}-8$ & 0.953 & 54.9 & $7.65 \mathrm{E}-3$ & 0.218 & 114.4 & 0.0014 \\
35 days & $0.10 \mathrm{Cr}$ & 1.4 & $1.31 \mathrm{E}-8$ & 0.974 & 248.1 & $2.59 \mathrm{E}-3$ & 0.219 & 536.6 \\
& $0.20 \mathrm{Cr}$ & 1.1 & $9.52 \mathrm{E}-9$ & 0.985 & 377.0 & $2.10 \mathrm{E}-3$ & 0.121 & 548.0 & 0.0045 \\
& $0.50 \mathrm{Cr}$ & 1.2 & $9.15 \mathrm{E}-9$ & 0.989 & 440.6 & $1.71 \mathrm{E}-3$ & 0.118 & 616.7 & 0.0079 \\
49 days & $0.10 \mathrm{Cr}$ & 1.1 & $7.56 \mathrm{E}-9$ & 0.974 & 854.5 & $2.34 \mathrm{E}-3$ & 0.101 & 1214.5 & 0.01069 \\
& $0.20 \mathrm{Cr}$ & 1.3 & $9.02 \mathrm{E}-9$ & 0.961 & 1038.6 & $1.52 \mathrm{E}-3$ & 0.104 & 1291.9 & 0.0132 \\
& $0.50 \mathrm{Cr}$ & 0.9 & $1.12 \mathrm{E}-8$ & 0.962 & 1295.4 & $1.01 \mathrm{E}-3$ & 0.149 & 1633.7 & 0.0224 \\
98 days & $0.10 \mathrm{Cr}$ & 0.9 & $9.80 \mathrm{E}-9$ & 0.992 & 1188.0 & $5.87 \mathrm{E}-3$ & 0.134 & 2105.2 & 0.0249 \\
& $0.20 \mathrm{Cr}$ & 1.2 & $1.69 \mathrm{E}-8$ & 0.963 & 1588.3 & $3.01 \mathrm{E}-3$ & 0.192 & 3061.3 \\
& $0.50 \mathrm{Cr}$ & 1.3 & $2.56 \mathrm{E}-8$ & 0.975 & 2171.4 & $1.36 \mathrm{E}-3$ & 0.109 & 4915.1 & 0.0356 \\
\hline
\end{tabular}
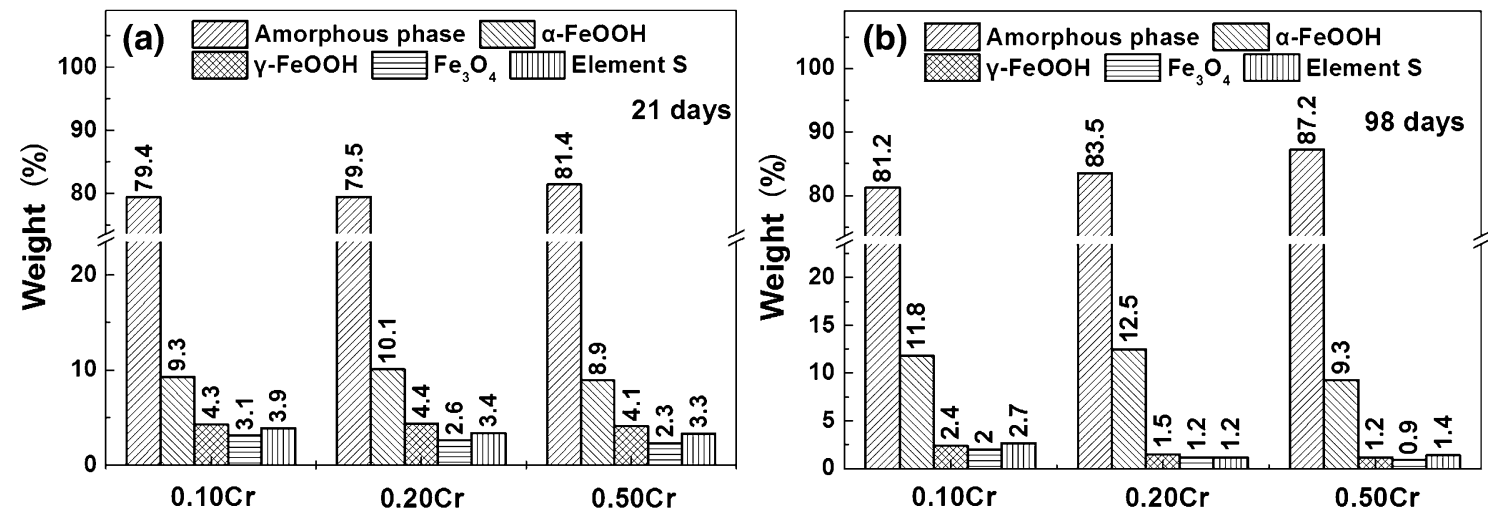

Fig. 9 Quantitative rust analysis of the tested steels at different corrosion time: a 21 days; b 98 days

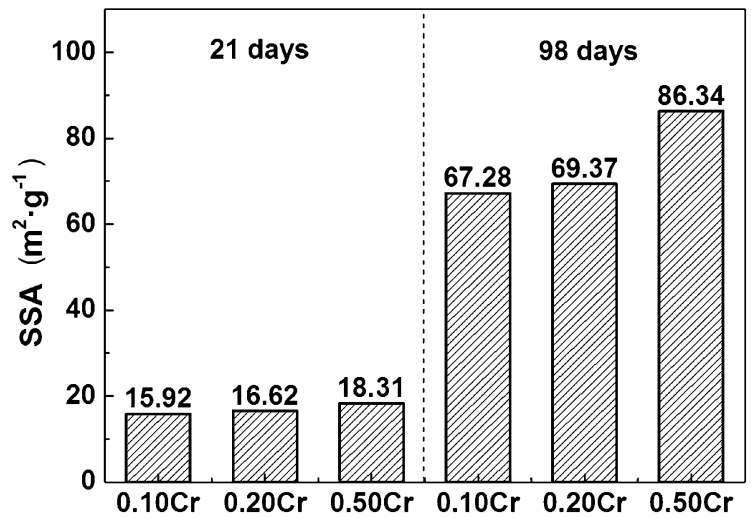

Fig. 10 SSA of the rust of the tested steels in wet-dry acid corrosion: a 21 days; $\mathbf{b} 98$ days of 21 days and increases obviously at corrosion time of 98 days. The results indicate that high content of $\mathrm{Cr}$ increases the compactness and barrier effect of rust in the long-term corrosion.

Figure 11 shows the surface morphologies of the rusts at corrosion time of 98 days. Figure 11a shows large cracks and pores on the rust of $0.10 \mathrm{Cr}$ steel. Figure $11 \mathrm{c}$ presents no cracks and lesser pores on the rust of $0.20 \mathrm{Cr}$ steel, and the size of the rust particles of $0.20 \mathrm{Cr}$ steel is also smaller than that of $0.10 \mathrm{Cr}$ steel. Figure $10 \mathrm{e}$ shows no obvious pores on the rust of $0.50 \mathrm{Cr}$ steel, which is the most compact among tested steels. The above results indicate that high content of $\mathrm{Cr}$ decreases the amount of the cracks and pores in the rust, as well as the size of the rust particles in the long-term corrosion. 

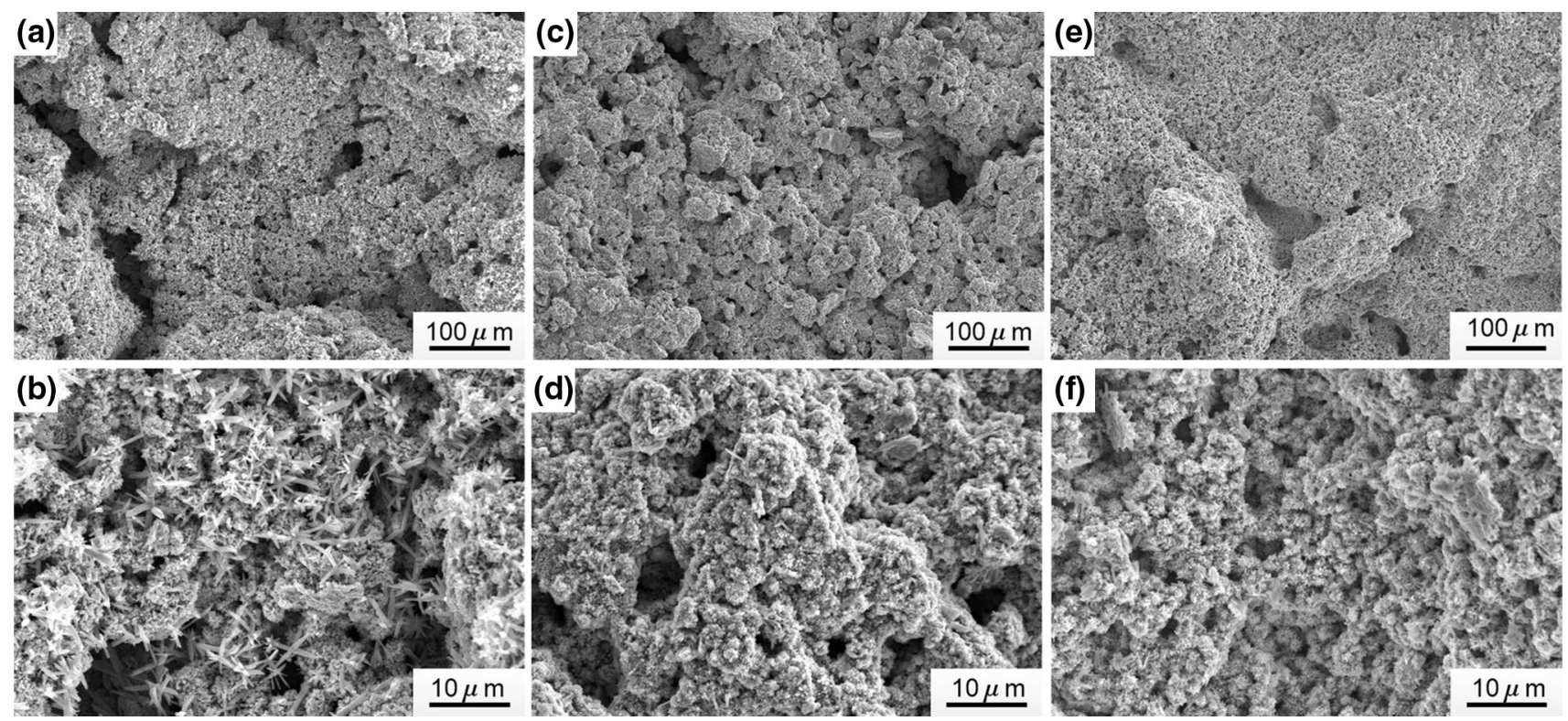

Fig. 11 Surface morphologies of the rusted steels at 98 days in wet-dry acid corrosion environment: a $0.10 \mathrm{Cr} ; \mathbf{b} 0.20 \mathrm{Cr}$; $\mathbf{c} 0.50 \mathrm{Cr}$

The surface morphologies of the rusts are observed in higher magnification to obtain more detailed information. Figure $11 \mathrm{~b}$ shows the bulky and acicular micron-sized rust particles of $0.10 \mathrm{Cr}$ steel, and the rust presents large pores facilitating the diffusion of corrosive species. Figure 11d indicates that the micron-sized rust particles disappear and the flocculent rust particles with lesser pores form on the surface of $0.20 \mathrm{Cr}$ steel, comparing with that of $0.10 \mathrm{Cr}$ steel in Fig. 11b. Figure 11f shows the nano-sized flocculent rust particles of $0.50 \mathrm{Cr}$ steel, which has the highest rust compactness among tested steels. The results indicate that the microstructure of the rust changes from micron-sized acicular rust to nano-sized flocculent rust with increasing content of $\mathrm{Cr}$, which decreases the grain size of the rust, and reduces the amount of the pores and cracks in the rust.

Figure 12 shows the cross-sectional morphologies of the rusts at corrosion time of 98 days. Rusts become thicker and compacter with increasing $\mathrm{Cr}$ content. The continuous pits are observed in the steel/rust interface of $0.10 \mathrm{Cr}$ and
$0.20 \mathrm{Cr}$ steel, which may be attributed to the co-existence of $\mathrm{O}_{2}$ and $\mathrm{SO}_{2}$ in wet-dry acid corrosion environment [30]. The corrosion morphology of the pits in steel/rust interface disappears when $\mathrm{Cr}$ content increases to $0.50 \mathrm{wt} \%$. The above results indicate that high $\mathrm{Cr}$ content increases the protectiveness of the rust, and also inhibits the inward diffusion of corrosive species, such as $\mathrm{SO}_{2}, \mathrm{H}_{2} \mathrm{~S}$ and $\mathrm{O}_{2}$.

Figure 13 gives TEM images and corresponding SAED patterns (insets) of $\alpha-\mathrm{FeOOH}$ and amorphous phases for the rusts at corrosion time of 98 days for $0.10 \mathrm{Cr}$ and $0.50 \mathrm{Cr}$ steel, respectively. Figure 13a, b shows the morphologies of crystalline $\alpha-\mathrm{FeOOH}$ and corresponding SAED from the points $\mathrm{A}$ and $\mathrm{B}$. $\alpha-\mathrm{FeOOH}$ of $0.50 \mathrm{Cr}$ steel is flaky and has much smaller particle size comparing with that of $0.10 \mathrm{Cr}$ steel, indicating that high content of $\mathrm{Cr}$ decreases the particle size of crystalline $\alpha$-FeOOH. SAED patterns of $\alpha$ $\mathrm{FeOOH}$ for $0.10 \mathrm{Cr}$ and $0.50 \mathrm{Cr}$ steel are quite different, due to the partial substitution of $\mathrm{Cr}^{3+}$ on position of $\mathrm{Fe}^{3+}$ in $\alpha$ $\mathrm{FeOOH}$ network $[6,7]$. Figure $12 \mathrm{c}, \mathrm{d}$ shows the compact (a)

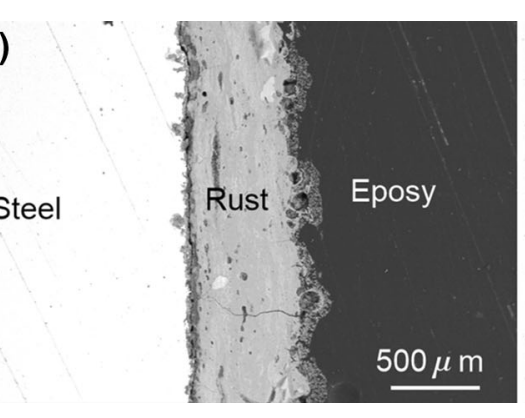

(b)

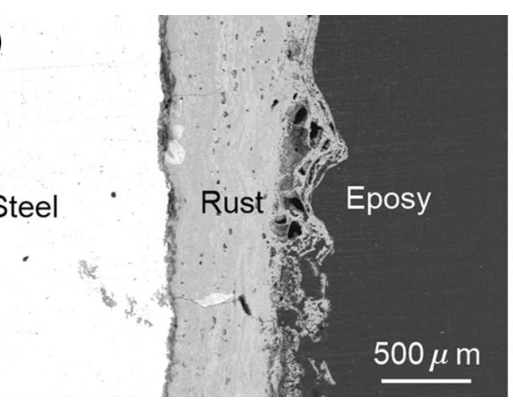

(c)

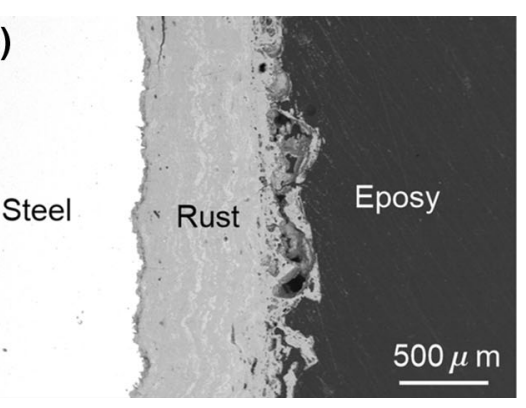

Fig. 12 Cross-sectional morphologies of the rusted steels at 98 days in wet-dry acid corrosion environment: a $0.10 \mathrm{Cr} ; \mathbf{b} 0.20 \mathrm{Cr}$; c $0.50 \mathrm{Cr}$ 

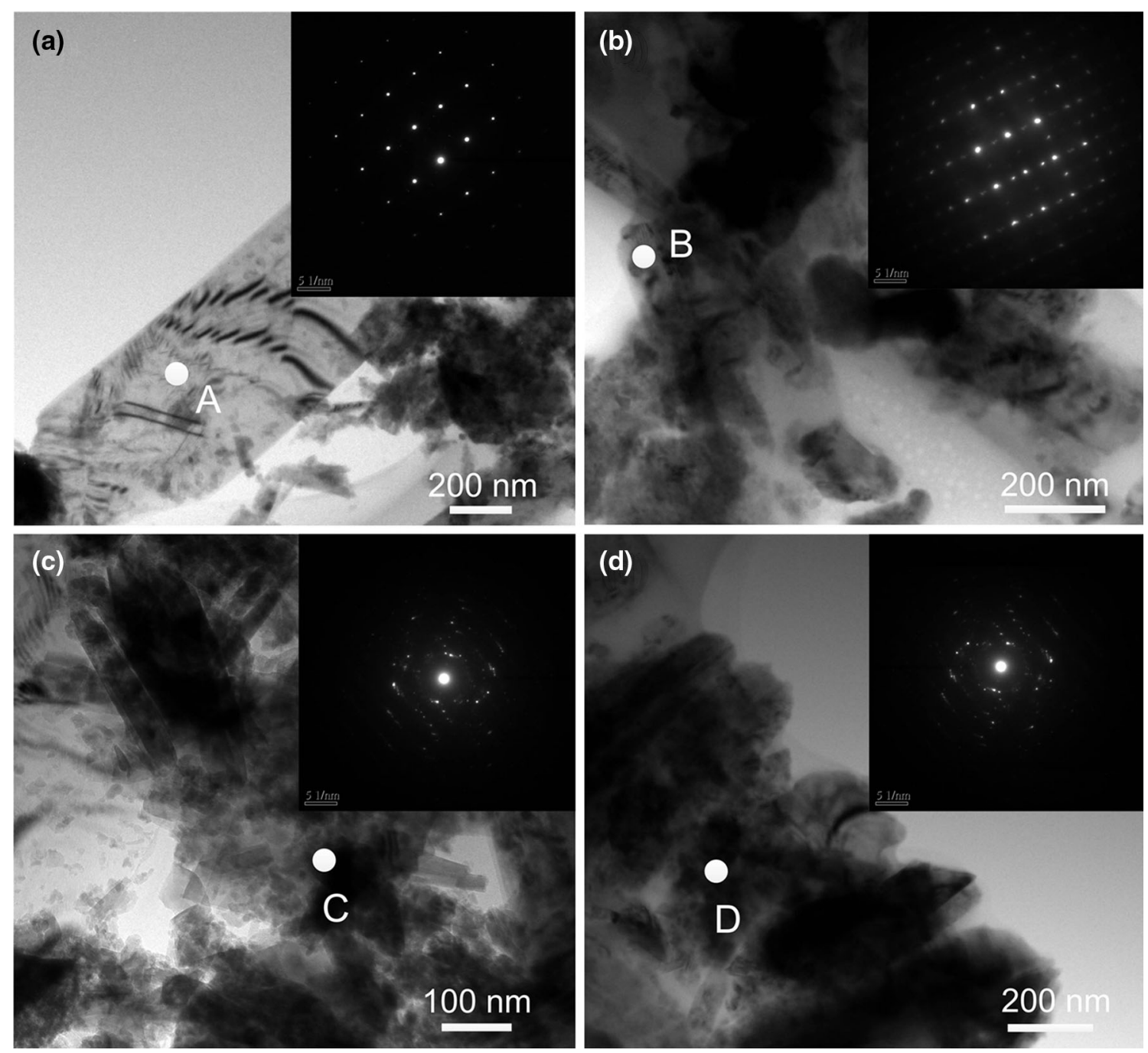

Fig. 13 TEM morphologies and corresponding SAED patterns (insets) of the rust for $0.10 \mathrm{Cr}$ and $0.50 \mathrm{Cr}$ steel at the corrosion time of 98 days: a $0.10 \mathrm{Cr} \alpha-\mathrm{FeOOH} ; \mathbf{b} 0.50 \mathrm{Cr} \alpha-\mathrm{FeOOH} ; \mathbf{c} 0.10 \mathrm{Cr}$ amorphous phase; $\mathbf{d} 0.50 \mathrm{Cr}$ amorphous phase

and homogeneous amorphous phase and corresponding SAED from the points $\mathrm{C}$ and $\mathrm{D}$, and presents a halo-like ED pattern for both $0.10 \mathrm{Cr}$ and $0.50 \mathrm{Cr}$ steel.

\section{Discussion}

The effect of small content of Cr on wet-dry acid corrosion behavior of low alloy steel has been investigated in this paper. Due to the higher activity of $\mathrm{Cr}$ than $\mathrm{Fe}$, high content of $\mathrm{Cr}$ accelerates the anodic dissolution process (Fig. 4), and then, the initial corrosion of the steel is promoted (Fig. 3). High initial corrosion rate of the steel results in the quick accumulation of the rust and promotes the formation of dense protective rust (Figs. 9, 10), leading to high rust resistance $R_{\text {rust }}$, charge transfer resistance $R_{\mathrm{ct}}$ and low corrosion current $i_{\text {corr }}$ of high $\mathrm{Cr}$ steel (Tables 3,5 ). Thus, high content of $\mathrm{Cr}$ depresses the long-term corrosion rate of the steel in wet-dry acid corrosion (Fig. 3). Rust with high density and compactness is the leading cause for good long-term corrosion resistance of high $\mathrm{Cr}$ steel in wet-dry acid corrosion condition.

The protectiveness of the rust is closely related to its composition. Rusts forming on steel surface mainly consist of amorphous phases, $\alpha$-FeOOH, $\gamma$-FeOOH, $\mathrm{Fe}_{3} \mathrm{O}_{4}$ and element $\mathrm{S}$. High content of $\mathrm{Cr}$ obviously increases the content of amorphous phases and slightly decreases the contents of $\alpha-\mathrm{FeOOH}$ and $\gamma-\mathrm{FeOOH}$ in the rusts (Fig. 8). Amorphous phases in the rust consist mainly of nano-sized ferric oxide or hydroxide, and are the main component of dense and protective rust [35]. Rust containing higher content of amorphous phases presents higher compactness, or higher barrier effect to corrosive species [33]. It is reported that $\alpha-\mathrm{FeOOH}$ can be transformed from amorphous phases through solid-state transformation during wet-dry corrosion [36, 37]. High content of $\mathrm{Cr}$ inhibits the 
phase transformation from amorphous phases to $\alpha-\mathrm{FeOOH}$, which is responsible for higher content of amorphous phases in the rust, as well as higher SSA of rust for $0.50 \mathrm{Cr}$ steel at corrosion time of 98 days (Fig. 9). $\gamma-\mathrm{FeOOH}$ is an effective cathodic depolarizer during electrochemical corrosion, which accelerates the corrosion of the steel [38]. In conclusion, high $\mathrm{Cr}$ content increases the rust compactness and electrochemical stability of the rusted steel in longterm corrosion by changing its composition.

The effect of alloying $\mathrm{Cr}$ on the formation of superfine rust is also illustrated. TEM results (Fig. 13) identified the doping of $\mathrm{Cr}^{3+}$ in amorphous phases and $\alpha-\mathrm{FeOOH}$, indicating that alloying $\mathrm{Cr}$ can participate in the formation process of ferric oxyhydroxides $\left(\left(\mathrm{Fe}_{x} \mathrm{Cr}_{1-x}\right) \mathrm{OOH}\right)$. Rust is mainly composed of several kinds of ferric oxyhydroxides $(\mathrm{FeOOH})$, i.e. amorphous phases, $\alpha-\mathrm{FeOOH}$ and $\gamma$-FeOOH. All kinds of $\mathrm{FeOOH}$ are composed of $\mathrm{Fe}(\mathrm{O}, \mathrm{OH})_{6}$ octahedra, but with different stacking sequences [39]. Alloying $\mathrm{Cr}$ can participate in the formation process of $\left(\mathrm{Fe}_{x}, \mathrm{Cr}_{1-x}\right)$ $(\mathrm{O}, \mathrm{OH})_{6}$ octahedra, and the $\left(\mathrm{Fe}_{x}, \mathrm{Cr}_{1-x}\right)(\mathrm{O}, \mathrm{OH})_{6}$ octahedra with higher content of doping $\mathrm{Cr}$ presents irregular sequence due to the difference of ion radius of $\mathrm{Cr}^{3+}$ and $\mathrm{Fe}^{3+}$, which makes $\mathrm{FeOOH}$ crystals difficult to grow up [40]. Thus, micron-sized rust particles can be observed in the rust of low $\mathrm{Cr}$ steel, and nano-sized rust particles are observed in the rust of high $\mathrm{Cr}$ steel (Fig. 11). The Crdoping ferric oxyhydroxides with small particle size lead to lower amount of the voids and pores in the rust, which is responsible for the enhanced rust compactness of high $\mathrm{Cr}$ steel (Fig. 10). The protective rust with lesser cracks and pores inhibits the transportation of corrosive particles in the rust, such as $\mathrm{O}_{2}, \mathrm{SO}_{4}{ }^{2-}$, and then the long-term corrosion resistance of the steel is increased with increasing content Cr.

\section{Conclusions}

Effect of small content of $\mathrm{Cr}$ on the wet-dry acid corrosion behavior of low alloy steel is investigated, and the conclusions are as follows:

1. Steels present excellent corrosion performance with increasing $\mathrm{Cr}$ content from 0.10 to $0.50 \mathrm{wt} \%$ in wetdry acid corrosion.

2. High content of $\mathrm{Cr}$ promotes anodic dissolution of bare steel and accelerates the initial corrosion. When dense and protective rust forms, high $\mathrm{Cr}$ content increases rust resistance $R_{\text {rust }}$ and charge transfer resistance $R_{\mathrm{ct}}$, lowers corrosion current $i_{\text {corr }}$ of the rusted steel in long-term corrosion.

3. The corrosion resistance of the rusted steels is closely related to rust composition. Rusts are all composed of amorphous phases, $\alpha$-FeOOH, $\gamma$-FeOOH, $\mathrm{Fe}_{3} \mathrm{O}_{4}$ and element $\mathrm{S}$. High content of $\mathrm{Cr}$ obviously increases the content of amorphous phases and slightly decreases the content of $\gamma-\mathrm{FeOOH}$, leading to high rust compactness and electrochemical stability of the rusted steel in long-term corrosion.

4. High content doping $\mathrm{Cr}$ in the ferric oxyhydroxides in the rusts inhibits the transformation from amorphous phases to $\alpha-\mathrm{FeOOH}$ and increases content of amorphous phases in the rust, which is responsible for the high rust compactness of high $\mathrm{Cr}$ steel.

Acknowledgements The authors thank for the funding support from the National Natural Science Foundation of China (Project No. 51571027).

\section{References}

[1] Z.G. Liu, X.H. Gao, C. Yu, L.X. Du, J.P. Li, P.J. Hao, Acta Metall. Sin. (Engl. Lett.) 28, 739 (2015)

[2] Q. Guo, J.H. Liu, M. Yu, S.M. Li, Acta Metall. Sin. (Engl. Lett.) 28, 139 (2015)

[3] Z. Wang, J. Liu, R. Han, Y. Sun, Corros. Sci. 67, 1 (2013)

[4] H.E. Townsend, Corrosion 57, 497 (2001)

[5] M. Sun, M. Luo, C. Lu, J. Li, Acta Metall. Sin. (Engl. Lett.) 28, 1089 (2015)

[6] M. Yamashita, H. Miyuki, Y. Matsuda, H. Nagano, T. Misawa, Corros. Sci. 36, 283 (1994)

[7] M. Yamashita, T. Shimizu, H. Konishi, J. Mizuki, H. Uchida, Corros. Sci. 45, 381 (2003)

[8] K. Asami, M. Kikuchi, Mater. Trans. 43, 2812 (2002)

[9] T. Kamimura, M. Stratmann, Corros. Sci. 43, 429 (2001)

[10] T. Kaminura, S. Hara, H. Miyuki, M. Yamashita, H. Uchida, Corros. Sci. 48, 2799 (2006)

[11] K. Aasmi, M. Kikuchi, Corros. Sci. 45, 2671 (2003)

[12] H. Tamura, Corros. Sci. 50, 1872 (2008)

[13] M. Yamashita, H. Konishi, J. Mizuki, H. Uchida, Mater. Trans. 45, 1920 (2004)

[14] M. Yamashita, H. Miyuki, H. Nagano, T. Misawa, compositional gradient and ion selectivity in $\mathrm{Cr}$ substituted goethite consisting the final stable protective rust layer on a weathering steel, in Paper presented at the 13th International Corrosion Congress, Melbourne, 7-10 January 1996

[15] M. Yamashita, H. Uchida, Hyperfine Interact. 139, 153 (2002)

[16] Y.H. Qian, D. Niu, J.J. Xu, M.S. Li, Corros. Sci. 71, 72 (2013)

[17] T. Kamimura, S. Nasu, T. Segi, T. Tazaki, S. Morimoto, H. Miyuki, Corros. Sci. 45, 1863 (2003)

[18] X. Lin, W. Liu, F. Wu, C. Xu, J. Dou, M. Lu, Appl. Surf. Sci. 329, 104 (2015)

[19] C.G. Soares, Y. Garbatov, A. Zayed, G. Wang, Corros. Sci. 50, 3095 (2008)

[20] Y. Yamaguchi, S. Terashima, Development of guidelines on corrosion resistant steels for cargo oil tanks, in Paper presented at the ASME 2011 30th International Conference on Ocean, Offshore and Arctic Engineering, American Society of Mechanical Engineers, 19-24 June 2011

[21] F.L. Sun, X.G. Li, X.Q. Cheng, Acta Metall. Sin. (Engl. Lett.) 27, 115 (2014)

[22] K. Kashima, Y. Tanino, S. Kubo, A. Inami, H. Miyuki, Development of corrosion resistant steel for cargo oil tanks, in Paper 
presented at the International Symposium on Shipbuilding Technology-Fabrication and Coatings, Osaka, 2007

[23] H. Shiomi, M. Kaneko, K. Kashima, H. Imamura, T. Komori, Development of anti-corrosion steel for cargo oil tanks, in Presented at the TSCF 2007 Shipbuilders Meeting, Busan, 2007

[24] IMO, Performance standard for alternative means of corrosion protection for cargo oil tanks of crude oil tankers, in Paper presented at the Marine Safety Committee on its Eighty-seventh Session Annex 3 MSC 289(87), London, 2010

[25] J. Guo, S. Yang, C. Shang, Y. Wang, X. He, Corros. Sci. 51, 242 (2008)

[26] L. Hao, S. Zhang, J. Dong, W. Ke, Corros. Sci. 59, 270 (2012)

[27] F. Sun, X. Li, F. Zhang, X. Cheng, C. Zhou, N. Wu, Y. Yin, J. Zhao, Acta Metall. Sin. 26, 257 (2013)

[28] S. Hœrlé, F. Mazaudier, P. Dillmann, G. Santarini, Corros. Sci. 46, 1431 (2004)

[29] T. Von Kármán, H.W. Emmons, G. Taylor, R.S. Tankin, J. Electrochem. Soc. 104, 751 (1957)

[30] J. Jankowski, R. Juchniewicz, Corros. Sci. 20, 841 (1980)
[31] W. Lv, C. Pan, W. Su, Z. Wang, S. Liu, C. Wang, J. Mater. Eng. Perform. 24, 2597 (2015)

[32] L. Hao, S. Zhang, J. Dong, W. Ke, Corros. Sci. 54, 244 (2012)

[33] T. Ishikawa, T. Yoshida, K. Kandori, T. Nakayama, S. Hara, Corros. Sci. 49, 1468 (2007)

[34] T. Ishikawa, R. Tanaka, M. Minamigawa, K. Kandori, H. Tanaka, T. Nakayama, Mater. Corros. 66, 1460 (2015)

[35] T. Ishikawa, K. Kandori, M. Kumagai, A. Yasukawa, Corrosion 57, 346 (2001)

[36] P. Dillmann, F. Mazaudier, S. Hoerle, Corros. Sci. 46, 1401 (2004)

[37] T. Ishikawa, K. Takeuchi, K. Kandori, T. Nakayama, Colloids Surf. A 266, 155 (2005)

[38] H. Antony, L. Legrand, L. Maréchal, S. Perrin, Ph Dillmann, A. Chaussé, Electrochim. Acta 51, 745 (2005)

[39] M. Kimura, H. Kihira, N. Ohta, M. Hashimoto, T. Senuma, Corros. Sci. 47, 2499 (2005)

[40] M. Kimura, T. Suzuki, G. Shigesato, H. Kihira, K. Tanabe, Nippon Steel Tech. Rep. 87, 17 (2003) 